\title{
Kontribusi Penggunaan Personal Selling Dalam Kegiatan Komunikasi Pemasaran Pada Era Pemasaran Masa Kini
}

\author{
Suherman Kusniadji \\ Fakultas ilmu Komunikasi Universitas Tarumanagara \\ hermankusniadji@gmail.com
}

\begin{abstract}
In today's marketing era, consumers seem to have known about marketed products and no longer need explanation from a salesperson. The interaction between company and target consumers can be marketed through new media such as email, Facebook, WA, Instagram, and other forms. Such situations need to be in-depth researched in terms of whether personal selling contribution is still needed in marketing communication activities. Considering the uniqueness and personal selling advantages turns out that personal selling is an important partner that can not be replaced by other forms of marketing communications even if there is exposure to new media to promote products. The specialty of personal selling lies in its ability to interact directly to improvise the sales process through person to person communication.
\end{abstract}

Keywords: marketing communication, marketing, personal selling

\begin{abstract}
Abstrak
Dalam era pemasaran masa kini nampaknya konsumen dianggap sudah mengetahui tentang produk yang dipasarkan dan tidak memerlukan lagi penjelasan dari seorang wiraniaga. Interaksi perusahaan dengan pembeli sasaran dapat dilakukan melalui media baru seperti email, facebook, WA, instagram dan bentuk lainnya. Situasi demikianlah yang memerlukan kajian mendalam dalam kaitannya bagaimana peran personal selling dalam kegiatan komunikasi pemasaran di era digital? Memperhatikan keunikan dan kelebihan personal selling ternyata personal selling merupakan mitra penting yang tidak dapat tergantikan oleh bentuk komunikasi pemasaran lainnya sekalipun ada terpaan media baru untuk mempromosikan produk. Keistimewaan personal selling terletak pada kemampuannya untuk berinteraksi secara langsung untuk mengimprovisasi proses penjualan melalui komunikasi person to person.
\end{abstract}

Kata Kunci: komunikasi pemasaran, marketing, personal selling.

\section{Pendahuluan}

Pada era pemasaran masa kini untuk bersaing dalam bisnis yang semakin ketat seperti sekarang ini, era dimana produk hampir seragam, kegiatan komunikasi pemasaran juga dituntut untuk bisa mendukung diferensiasi dibandingkan dengan pesaing. Personal selling dapat digunakan sebagai salah satu unsur yang penting untuk mendukung kegiatan komunikasi pemasaran karena berbagai kelebihannya jika dibandingkan dengan bentuk komunikasi pemasaran lainnya. Tidak semua produk dapat dipasarkan secara efektif untuk diperkenalkan kepada konsumen hanya dengan menggunakan komunikasi pemasaran berupa 
iklan, sales promotion, publisitas, event dan berbagai bentuk komunikasi pemasaran lainnya. Apapun bentuknya kegiatan komunikasi pemasaran pada intinya bertujuan untuk memperkenalkan sebuah produk atau jasa kepada konsumen agar mereka tahu akan keberadaaan produknya. Ketika ada konsumen yang sudah tahu maka diharapkan konsumen tersebut dapat mengkomunikasikan kepada orang lain. Dalam kajian ilmu pemasaran diharapkan munculnya kesetiaan konsumen dengan harapan terjadinya pembelian ulang. Pembelian ulang ini terjadi karena adanya promosi positif dari konsumen sebelumnya.

Pemahaman tentang personal selling atau penjualan perseorangan adalah interaksi antara individu, saling bertatap muka yang ditujukan untuk menciptakan, memperbaiki, menguasai atau mempertahankan hubungan pertukaran yang saling menguntungkan dengan pihak lain. Komunikasi individu pada penjualan perorangan adalah terletak pada janji-janji mengenai keunggulan dan kelebihan dari produk yang ditawarkan oleh wiraniaga kepada pelanggan, sehingga pada saat itu pelanggan membeli produk yang ditawarkan dengan harapan bahwa kinerja dari produk sesuai dengan apa yang dijanjikan sebelumnya. Jika kinerja diharapkan jauh berada di bawah harapan pelanggan maka pelanggan tidak merasa puas dan sebaliknya. Apabila pelanggan merasa puas maka pelanggan tersebut akan terus membeli produk pada perusahaan yang dapat memberikan kepuasan tertentu bagi pelanggan.

\section{Metode Penelitian}

Metode yang digunakan dalam tulisan ini studi kepustakaan atau studi literatur mengenai komunikasi pemasaran, khususnya pembahasan mengenai personal selling. Tulisan ini berfokus pada kegiatan komunikasi pemasaran pada era pemasaran masa kini yang ditandai dengan era digital. Kemudian juga berfokus pada keunikan dari personal selling dibandingkan jenis komunikasi pemasaran lainnya.

\section{Hasil Penemuan dan Diskusi}

\section{Kegiatan Komunikasi Pemasaran Pada Era Pemasaran Masa Kini}

Kehadiran internet telah menjadi alat utama untuk pengiriman informasi, bisnis dari semua ukuran untuk meningkatkan kesadaran pelanggan terhadap barang dan jasa dengan mengacu pada kekuatan internet (media nirkabel) untuk menghasilkan respons tertentu dari konsumen. Dalam dunia marketing dikenal sebagai internet marketing, digital marketing, web marketing, online marketing, search engine marketing atau $e$ - marketing untuk menawarkan barang dan jasa secara langsung kepada konsumen atau dari bisnis ke bisnis secara online (Hasan, 2014)

Kehadiran perusahaan yang melakukan pemasaran digital dalam bentuk $E$ - commerce seperti: Tiket.Com, Zalora, Bukalapak, Lazada, Erafone. Com, Dinomarket.Com, Matahari Mall. Com, LAKUPON.Com dan lainnya tidak terlepas dari aktivitas komunikasi pemasaran berupa penawaran promo spektakuler yang khusus dihadirkan untuk mempengaruhi minat beli konsumen. 
Suherman Kusniadji : Kontribusi Penggunaan Personal Selling Dalam Kegiatan Komunikasi Pemasaran Pada Era Pemasaran Masa Kini

Pemasaran digital tidak lagi mempertimbangkan konsep jarak dan waktu untuk menjangkau konsumen karena adanya dukungan teknologi internet yang semakin canggih. Konsumen cukup memilki sebuah ponsel canggih dan berbagai alat komunikasi lainnrya untuk melihat promosi produk dalam pemasaran digital. Pertanyaan nya adalah apakah dalam situasi era pemasaran digital ini kehadiran personal selling masih dibutuhkan perannya? Sebagaimana dalam pemasaran tradisional kehadiran personal selling amat dibutuhkan untuk memberikan penjelasan tentang produk secara detail kepada konsumen serta untuk melakukan persuasi secara individu dan kelompok agar tercipta hubungan komunikasi untuk mendukung agar terciptanya sebuah transaksi pembelian. Kotler dan Keller dalam bukunya Marketing Management edisi 12 (2013) mengemukakan perusahaan harus menempatkan tenaga penjualan secara strategis sehingga mereka mengunjungi pelanggan yang tepat pada saat yang tepat dengan cara yang tepat. Saat ini wiraniaga bertindak sebagai "manager pelanggan" yang mengatur hubungan yang produktif antara orang-orang dalam organisasi pembelian dan penjualan.

Dalam era pemasaran digital, nampaknya konsumen dianggap sudah mengetahui tentang produk yang dipasarkan dan tidak memerlukan lagi penjelasan dari seorang wiraniaga. Interaksi perusahaan dengan pembeli sasaran dilakukan melalui email, facebook, WA, instagram dan lainnya sebagai media komunikasi untuk menjalin hubungan komunikasi dalam proses transaksi bisnis. Situasi demikian lah yang memerlukan kajian mendalam dalam kaitannya apakah kontribusi personal selling masih dibutuhkan. Untuk itu perlu dilakukan pengamatan terhadap produk- produk yang ditawarkan oleh perusahaan yang melakukan kegiatan pemasaran digital. Dalam praktek pemasaran ternyata masih banyak perusahaan yang menggunakan personal selling untuk mengkomunikasikan produk dan jasanya. Dalam era komunikasi pemasaran digital yang penuh dengan situasi persaingan, menuntut setiap salesperson untuk meningkatkan profesionalisme di bidangnya. Dalam kondisi demikian setiap salesperson tidak hanya dituntut untuk menjadi penerima pesanan yang pasif tetapi harus mampu menjadi seorang salesperson menjadi pencari pesanan produk dan jasa sebuah perusahaan yang aktif. Selain itu, salesperson tidak hanya dituntut untuk dapat melakukan fungsi selling secara efektif tetapi juga harus mampu membangun hubungan jangka panjang yang menguntungkan dengan pelanggan. Tentunya hubungan jangka panjang tersebut sebaiknya tidak hanya dengan konsumen, tetapi perlu juga dengan supplier dan pihak-pihak yang berkepentingan dengan perusahaan (stakeholder).

\section{Keunikan personal selling dibandingkan dengan bentuk komunikasi pemasaran lainnya}

Personal selling memiliki karakteristik yang berbeda dengan alat - alat promosi lainnya. Nilai unit yang tinggi, keperluan akan penjelasan produk, karakteristik produk yang kompleks, detail barang yang perlu penjelasan merupakan sebagian karakteristik yang bisa digunakan sebagai alasan penerapan penjualan personal Hermawan (2012). Sedangkan menurut Sutisna (2001), personal selling memiliki keunggulan, yaitu: 
1. Personal selling melibatkan komunikasi secara langsung dengan konsumen potensial, sehingga lebih bisa membujuk daripada alat - alat promosi lain.

2. Proses komunikasi face to face menjadikan komunikasi potensial lebih memperhatikan pesan dari komunikator.

3. Personal selling dapat mendesain cara penyampaian pesan yang berbeda sesuai dengan situasi dan kondisi audien.

4. Dalam personal selling terjadi komunikasi dua arah, sehingga dapat memungkinkan adanya dialog interaktif antara salesperson dengan konsumen.

5. Personal selling lebih memungkinkan untuk menyampaikan pesan yang kompleks mengenai suatu produk yang tidak dapat disampaikan melalui iklan.

Sedangkan menurut Hermawan (2012), karena sifat-sifat dari personal selling, maka metode personal selling memiliki kelebihan antara lain: operasinya lebih fleksibel karena penjual dapat mengamati reaksi pelanggan dan menyesuaikan pendekatannya, usaha yang sia-sia dapat diminimalkan, pelanggan yang berminat biasanya langsung membeli, dan penjual dapat membina hubungan jangka panjang dengan pelanggannya. Namun karena menggunakan armada penjual yang relative besar, maka metode ini biasanya mahal. Di samping itu, spesifikasi penjual yang diinginkan perusahaan mungkin sulit dicari. Meskipun demikian, penjualan personal tetaplah penting dan biasanya dipakai untuk mendukung metode promosi lainnya (Hermawan, 2012). Kelebihan lainnya dari metode personal selling bila dibandingkan dengan metode komunikasi pemasaran lainnya adalah ketika salespeople menyampaikan informasi yang kompleks mengenai karakteristik produk yang tidak mungkin dapat disampaikan oleh metode periklanan. Salesforce dapat mendemonstrasikan produk dengan dukungan teknik audiovisual. Salespeople memiliki peran yang penting dalam membangun hubungan jangka panjang antara pembeli dan penjual dengan membangun relationship dalam business to business customers.

Dalam praktek komunikasi pemasaran, perusahaan menggunakan personal selling agar mudah melakukan komunikasi tatap muka dengan konsumen. Dengan menggunakan personal selling dapat menciptakan kondisi dialogis antara sales sebagai komunikator dengan konsumen sebagai komunikan secara face to face. Hal ini sesuai dengan pendapat Soemanagara (2006) yang menurutnya dalam komunikasi face to face, terdapat dua jenis feedback yaitu immediate feedback atau respon yang diperoleh seketika dan delayed feedback atau terjadi penundaan respon dari komunikan. Penundaan respon terjadi pada waktu konsumen hendak mempelajari maksud utama dari pesan yang disampaikan oleh komunikator dan memungkinkan timbulnya sebuah respon atas pesan lebih lambat dari yang diperkirakan. Manfaat lainnya yang diperoleh dari personal selling adalah kegiatan personal selling mampu menciptakan suatu aktivitas komunikasi pemasaran karena selain ada interaksi komunikasi dua arah antara penjual dan pembeli, personal selling juga mampu menjelaskan produk yang ditawarkan secara jelas dan meyakinkan sehingga mampu mempengaruhi serta membujuk 
Suherman Kusniadji : Kontribusi Penggunaan Personal Selling Dalam Kegiatan Komunikasi Pemasaran Pada Era Pemasaran Masa Kini

pembeli untuk membeli produk yang ditawarkan. Berkenaan dengan personal selling, Hans Ouwersloot dan Tom Duncan (2008) mengemukakan :

"Personal selling is interpersonal communications in which a sales person uncovers and satisfies the needs of a customer to the mutual benefit of both. In many business to business ( $B$ to $B$ ) categories, personal selling is the dominant marketing communication function"

Jika sebuah perusahaan memliki pelanggan seperti hypermarket, supermarket serta pengecer modern maka personal selling cocokdigunakan sebagai strategi utama dalam kegiatan komunikasi pemasaran dan sejalan dengan apa yang dikemukakan oleh Ouwersloot dan Duncan (2008), personal selling adalah komunikasi interpersonal di mana penjual mengungkapkan dan memuaskan kebutuhan pelanggan, yang dapat saling menguntungkan kedua belah pihak. Komunikasi interpersonal dibutuhkan untuk menjalin keakraban antara wiraniaga selaku personal selling dengan pelanggan. Keakraban ini penting agar lebih mempermudah proses penjualan produk perusahaan kepada pelanggan. Kontribusi personal selling sangat dibutuhkan dalam mendukung komunikasi pemasaran karena adanya beberapa produk yang dipasarkan memerlukan penjelasan dan peragaan gambar, foto, atau keterangan-keterangan, informasi adanya produk baru, spec baru, keunggulan produk, melakukan deals dengan pelanggan dan lain-lain. Untuk menjangkau pelanggan pasar modern seperti Hypermarket dan Supermarket, personal selling dibutuhkan untuk taking order regular misalnya ketika seorang wiraniaga berkomunikasi dengan pimpinan modern market untuk membicarakan tentang sewa tempat, penjualan berbonus, penjualan dengan diskon khusus, dan lainnya.

Selanjutnya menurut Sutisna (2001), peran yang dapat dilakukan oleh personal selling adalah:

1. Menyampaikan pesan yang kompleks kepada konsumen potensial mengenai produk atau jasa dan kebijakan perusahaan.

2. Mengadaptasi penawaran atau daya tarik promosional produk untuk kebutuhan yang unik dan konsumen yang spesifik.

3. Membujuk konsumen bahwa produk atau jasa perusahaan lebih unggul daripada pesaing.

Sebagai salah satu alat yang dapat digunakan dalam kegiatan komunikasi pemasaran, personal selling cukup efektif dalam membangun preferensi, keyakinan dan tindakan pembelian. Selanjutnya Hasan (2014), berpendapat personal selling memiliki tiga manfaat sebagai berikut :

1. Personal confrontation, yaitu:

- Mencakup hubungan yang dinamis, harmonis, langsung dan interaktif antara dua pelanggan atau calon pelanggan atau lebih.

- Pengamatan personal membentuk kemampuan untuk saling menyesuaikan.

2. Cultivation, yaitu :

- Memungkinkan timbulnya berbagai jenis hubungan mulai dari hubungan penjualan sampai ke hubungan persahabatan. 
- Penjualan personal akan sangat efektif, apabila seller mengutamakan kepentingan pelanggan guna mempertahankan hubungan pembelian jangka penjang.

3. Response, yaitu:

- Membuat calon pembeli merasa berkewajiban untuk mendengarkan pembicaraan seller.

- Calon pembeli terkadang "terpaksa" harus menanggapi, walaupun hanya sekedar ucapan "terima kasih" secara sopan.

Ketika memperhatikan keunggulan, peran dan manfaat dari personal selling maka walaupun personal selling merupakan cara mempromosikan produk yang tertua di dunia, namun memiliki keunikan tersendiri jika dibandingkan dengan metode atau alat komunikasi pemasaran lainnya. Hal ini dapat dilihat dari aktivitas personal sebagai wiraniaga ketika berhadapan secara langsung dengan konsumen, seorang wiraniaga dapat berkomunikasi secara interaktif untuk menjelaskan produk secara terperinci baik tentang spesifikasi, fungsi, manfaat, jenis, harga, cara pembayaran, pengiriman dan lainnya. Keistimewaan personal selling terletak pada kemampuannya berkomunikasi dari wiraniaga untuk berinteraksi langsung dengan pelanggan. Bila memperhatikan beberapa bentuk komunikasi pemasaran yang ada maka personal selling merupakan mitra penting yang tidak dapat tergantikan oleh bentuk komunikasi pemasaran lainnya sekalipun dalam era internet marketing di abad modern ini. Kemampuan personal selling mampu improvisasi dari penjualan dengan komunikasi person to person. Kekuatan personal selling adalah mampu menjelaskan produk perusahaan secara detail, menginformasikan produk baru, spec baru, keunggulan produk dan deals dengan pelanggan. Seperti apa yang dikemukakan oleh Hermawan (2012), penjualan personal merupakan interaksi langsung dengan satu calon pembeli atau lebih guna melakukan persentasi, menjawab pertanyaan, menerima pesanan. Penjualan personal adalah komunikasi langsung (tatap muka) antara penjual dan calon pelanggan untuk memperkenalkan suatu produk kepada calon pelanggan dan membentuk pemahaman pelanggan terhadap produk sehingga mereka kemudian akan mencoba dan membelinya. Penjualan personal merupakan alat yang paling efektif - biaya pada tahap proses pembelian lebih lanjut, terutama dalam membangun preferensi, keyakinan, dan tindakan pembeli.

\section{Strategi Personal Selling Untuk Mendukung Kegiatan Komunikasi Pemasaran}

Walaupun kegiatan pemasaran sebuah produk dapat dilakukan dengan mengunakan beberapa atau kombinasi dari bentuk bentuk komunikasi pemasaran, personal seliing memiliki sifat keunikan yaitu adanya tatap muka langsung dengan konsumen. Inilah peran penting dari personal selling yang tidak tergantikan oleh bentuk komunikasi pemasaran lainnya. Dalam kajian pemasaran , seperti dengan apa yang dikemukakan oleh Kotler dan Keller (2012) bauran komunikasi pemasaran (marketing communication mix) terdiri dari 8 (delapan) model komunikasi utama, yaitu : iklan, promosi penjualan, acara dan pengalaman, hubungan masyarakat dan publisitas, pemasaran langsung, pemasaran interaktif, 
Suherman Kusniadji : Kontribusi Penggunaan Personal Selling Dalam Kegiatan Komunikasi Pemasaran Pada Era Pemasaran Masa Kini

pemasaran dari mulut ke mulut dan penjualan personal. Penjualan personal merupakan bentuk komunikasi pemasaran yang tertua dengan mengedepankan kunjungan penjualan lapangan. Menurut Kotler \& Keller (2012) saat ini sebagian besar perusahaan industri sangat bergantung pada tenaga penjualan professional untuk menemukan tempat calon pelanggan, mengembangkannya menjadi pelanggan, dan menumbuhkan bisnis, atau mereka mempekerjakan perwakilan produsen dan agen untuk melaksanakan tugas penjualan langsung. Selanjutnya banyak perusahaan konsumen seperti Allstate, Avon, Amway, Mary Kay, Merryll Lynch dan Tupperware menggunakan tenaga penjualan langsung.

Untuk mendukung kegiatan komunikasi pemasaran, perusahaan perlu menempatkan tenaga penjualan secara strategis sehingga mereka mengunjungi pelanggan yang tepat pada saat yang tepat dengan cara yang tepat. Saat ini wiraniaga bertindak sebagai "manajer pelanggan" yang mengatur hubungan yang produktif antara orang-orang dalam organisasi pembelian dan penjualan (Kotler \& Keller, 2012).

\section{Simpulan}

Tidak semua produk baik berupa barang atau jasa dapat dipasarkan secara efektif untuk diperkenalkan dan dikomunikasikan kepada konsumen hanya dengan menggunakan iklan, sales promotion, publisitas dan berbagai bentuk komunikasi pemasaran lainnya. Kehadiran personal selling sebagai salah satu metode komunikasi pemasaran dengan berbagai kelebihannya sangat diperlukan kontribusinya dalam kegiatan pemasaran di masa kini. Keistimewaan metode personal selling terletak pada kemampuannya berkomunikasi dari salesforce untuk berinteraksi langsung dengan pelanggan. Bila beberapa bentuk komunikasi pemasaran yang ada maka personal selling merupakan mitra penting yang tidak dapat tergantikan oleh bentuk komunikasi pemasaran lainnya sekalipun dalam era internet marketing di abad modern ini. Kontribusi penggunaan personal selling masih dibutuhkan dalam era pemasaran masa kini karena masih adanya produkproduk yang dipasarkan memerlukan penjelasan peragaan gambar, foto, manfaat teknis, spesifikasi, spec baru, keunggulan lainnya, kebutuhan untuk negosiasi dengan pelanggan, dan lainnya.

\section{Ucapan Terima Kasih}

Penulis mengucapkan terima kasih kepada seluruh anggota Fakultas Ilmu Komunikasi Universitas Tarumanagara atas dukungannya selama penulisan artikel ini.

\section{DAFTAR PUSTAKA}

Agus Hermawan, (2002), Komunikasi Pemasaran. Jakarta: Erlangga.

Ali Hasan, (2013). Marketing, Dan Kasus - Kasus Pilihan, Center For Academic PublishIng Service. 
Kennedy E. John., \& Soemanagara, Dermawan R. (2009). Marketing Communication, Taktik \& Strategy. Jakarta: PT Bhuana Ilmu Populer.

Kotler, Philip., \& Keller. (2012). Marketing Management. USA: Pearson Education, inc.

Ouwersloot, Hans., \& Duncan, Tom, (2008). Integrated Marketing Communications. USA: Mc Graw - Hill Education.

Sutisna. (2001). Perilaku Konsumen \& Komunikasi Pemasaran, Bandung: Remaja Rosdakarya, 